NBER WORKING PAPER SERIES

\title{
LABOR MARKET EFFECTS OF PAYROLL TAXES IN DEVELOPING COUNTRIES: EVIDENCE FROM COLOMBIA
}

\author{
Adriana Kugler \\ Maurice Kugler \\ Working Paper 13855 \\ http://www.nber.org/papers/w13855 \\ NATIONAL BUREAU OF ECONOMIC RESEARCH \\ 1050 Massachusetts Avenue \\ Cambridge, MA 02138 \\ March 2008
}

\begin{abstract}
We are grateful to Josh Angrist, Samuel Bentolila, Paul Gertler, Jon Gruber, Ricardo Hausmann, Larry Lau, Bill Maloney, Barry McCormick, David McKenzie, Ernesto May, John Pencavel, Luigi Pistaferri, John Strauss, an associate editor and two anonymous referees, and seminar participants at Southampton, Stanford and the Latin American and Caribbean Economic Association meetings in Madrid for very useful comments, as well as to the World Bank for providing financial support fo the study. Zheng Wang provided valuable research assistance. The econometric analysis of plant-level data from the Manufacturing Census was made possible by the hospitality from Departamento Administrativo Nacional de Estadistica (Colombian Bureau of National Statistics), Banco de la Republica de Colombia, and Stanford University while the second author was visiting. Please address correspondence to: adkugler@uh.edu and Maurice_Kugler@harvard.edu. The views expressed herein are those of the author(s) and do not necessarily reflect the views of the National Bureau of Economic Research.
\end{abstract}

NBER working papers are circulated for discussion and comment purposes. They have not been peerreviewed or been subject to the review by the NBER Board of Directors that accompanies official NBER publications.

(C) 2008 by Adriana Kugler and Maurice Kugler. All rights reserved. Short sections of text, not to exceed two paragraphs, may be quoted without explicit permission provided that full credit, including $\odot$ notice, is given to the source. 
Labor Market Effects of Payroll Taxes in Developing Countries: Evidence from Colombia Adriana Kugler and Maurice Kugler

NBER Working Paper No. 13855

March 2008

JEL No. H2,J3

\begin{abstract}
We use a panel of manufacturing plants from Colombia to analyze how the rise in payroll tax rates over the 1980s and 1990s affected the labor market. Our estimates indicate that formal wages fall by between $1.4 \%$ and $2.3 \%$ as a result of a $10 \%$ rise in payroll taxes. This "less-than-full-shifting" is likely to be the result of weak linkages between benefits and taxes and the presence of downward wage rigidities in Colombia. Because the costs of taxation are only partly shifted from employers to employees, employment also falls. Our results indicate that a $10 \%$ increase in payroll taxes lowered formal employment by between $4 \%$ and $5 \%$. In addition, we find some evidence of less shifting and larger disemployment effects for production than for non-production workers. These results suggest that policies aimed at boosting the relative demand of less-skill workers by reducing social security taxes may be effective in Latin American countries, where minimum wages bind and benefits are often not directly linked to contributions.
\end{abstract}

\author{
Adriana Kugler \\ University of Houston \\ Department of Economics \\ 204 McElhinney Hall \\ Houston, TX 77204-5019 \\ and NBER \\ adkugler@uh.edu \\ Maurice Kugler \\ Center for International Development \\ Kennedy School of Government \\ Harvard University \\ Cambridge MA 02138 \\ Maurice_Kugler@ksg.harvard.edu
}




\section{Introduction}

Latin American and other developing countries, like developed countries, rely on payroll taxes to finance the provision of pensions, benefits for disability and maternity, and compensation for work injuries for employees. Mandated contributions in Latin America are on average close to European levels, but much higher in some countries such as Argentina, Colombia, and Uruguay were payroll taxes are around 40\% (Gill, Truman and Yermo (2005)). In Europe, the countries with the highest mandated contributions face payroll taxes as high as $30 \%$ and in the less-regulated British and North American labor markets these contributions are between $15 \%$ and $20 \%$.

In Latin America, like in Europe, high payroll taxes have often been blamed for the high labor costs faced by employers and for discouraging employment. However, the theoretical analysis of payroll taxation is ambiguous in terms of the impact of payroll taxes on labor markets. When workers value the benefits financed through payroll taxes as much as the contributions cost employers, rises in payroll taxes should be fully shifted from firms to employees in the form of lower wages with no disemployment effects. On the other hand, if wages are rigid or payroll taxes finance benefits not fully accrued by employees, workers will not absorb the entire cost of the payroll taxes and employment will fall.

Empirical evidence on the impact of payroll taxation for different countries is also mixed. Previous results range from full-shifting to little shifting and large disemployment effects. ${ }^{1}$ Studies that exploit both cross-section and time series variation seem most likely to find full shifting. For example, Gruber (1994, 1997) and Gruber and Krueger (1991),

\footnotetext{
${ }^{1}$ Even for a single country, there is often a wide range of results. For example, for the U.S., Gordon (1972) finds full-shifting; Hamermesh (1979) and Vroman (1974) less-than-full-shifting, and Kaester (1996) finds no shifting for young workers. Hamermesh (1993), Blau and Kahn (1999) and Nickell and Layard (1999) provide excellent reviews of studies on the impact of payroll taxes for various countries as well as of crosscountry analyses.
} 
which rely on cross-section and time-series variation in Chile for social security contributions and in the U.S. for disability insurance and maternity benefits, find full wage shifting of employer contributions and no disemployment effects. Gruber (1997) notes, however, that "applicability of the [U.S.] studies to other types of payroll taxation and to other countries is uncertain.” This is partly because there may be a closer tax-benefit linkage in the case of disability benefits and maternity health insurance than in the case of savings for retirement. In addition, Gruber (1994) and Gruber and Krueger (1991) consider relatively small increases in payroll taxes in the U.S. which can be easily passed on as lower wages. By contrast, Gruber (1997) considers a large reduction in payroll taxes following the privatization of the social security system in Chile which was passed on to workers as higher wages. However, given labor market rigidities and weak linkages between benefits and contribution in most of Latin America, the study for Chile may not be generalized in terms of the labor market consequences of payroll taxes in Latin America. Given binding minimum wages in Latin America (see, e.g., Maloney and Núñez, 2004), it may be more difficult to pass a large increase in payroll taxes on to workers as lower wages than to pass a large reduction in payroll taxes as higher wages as was the case in Chile. Moreover, most Latin American countries rely on pay-as-you-go social security systems and face weak linkages between pensions and other benefits, on the one hand, and contributions, on the other, which would make workers less willing to pay for the benefits in the form of lower wages and encourage them to move to the informal sector. ${ }^{2}$

As in Gruber (1997), we examine the effects of changes in payroll taxes on formal employment and wages in Latin America. However, contrary to Gruber (1997), we look at

\footnotetext{
${ }^{2}$ See Maloney (2004, 1999), Maloney and Bosch (2006), Maloney, Goni and Bosch (2007), and Levy (2006) for a view of the formal/informal sectors as characterized by large job-to-job movements and voluntary entry
} 
the effects of a large increase in payroll taxes in Latin America over the 1980s and 1990s and, in particular, at the large increase in payroll taxes for pensions and health of $10.5 \%$ following the Colombian social security reform of 1993 . It is especially interesting to contrast the Colombian and the Chilean cases because the effects of payroll taxes may be asymmetric. If wages are flexible upwards but not down, there could be full shifting in response to a large reduction in payroll taxes but not in response to a large increase. Recent studies suggest that minimum wages bind in Colombia and other Latin American countries (see Maloney and Núñez (2004) for evidence on Latin America, including Colombia, and Arango and Pachón (2004), Bell (1997) and Santamaría (1999) for further evidence on Colombia), pointing to an important source of downward wage rigidities in this continent.

Our study uses a balanced panel of plants in the formal sector from the Annual Survey of Manufacturers in Colombia over the period 1982-96. This data set has information on total contributions as well as on wages and employment. Following Gruber (1997), we construct tax rates for each plant by dividing total contributions by wages rather than by imputing tax rates as in other studies. Most of the variation we exploit is temporal variation in payroll taxes. In fact, average increases in the constructed tax rates closely correspond with the statutory changes in payroll taxes over time. While there is some crosssectional variation in the changes in tax rates in the Colombian data, these deviations of changes in tax rates above and below the statutory changes are very small. Moreover, the changes are distributed evenly above and below the statutory changes suggesting that these deviations are related to either true sources of variation (e.g., the degree of accident risk across plants) or measurement error. If deviations were due primarily to plants trying to

into the informal sector as a result of inefficiencies in formal sector protections. 
avoid paying taxes by either hiring informal or temporary workers, in which case we would observe deviations to be heavily skewed below the statutory tax increases.

Estimates controlling for plant-specific trends suggest that a 10\% increase in payroll taxes reduces wages by between $1.4 \%$ and $2.3 \%$ and employment by between $4 \%$ and $5 \%$. There also appears to be less shifting and greater disemployment for production than for non-production workers. Less shifting and more disemployment for production workers may be due to the fact that the minimum wage is more likely to bind for this group of workers. The weaker link between benefits and contributions for production workers could also be due to the fact that these workers are more likely to turn to the informal sector if their wages are lowered. An implication of these results is that reductions in payroll taxes for low-wage workers, often proposed as a way to boost the relative demand of low-skill workers, may be an effective measure to reduce unemployment and informal activity among young and unskilled workers in Latin America, especially if tax cuts are targeted to indirect benefits.

Besides our study, and Gruber (1997) before ours, other studies have looked at the impact of labor costs (including payroll taxes) in Latin America. Hamermesh (2004) provides a summary and interpretation of results in recent studies for Latin America. These studies, however, construct variables of labor costs that pool payroll taxes with either wages or dismissal costs, making it difficult to interpret the effect of payroll taxes alone. A number of studies for Latin America, instead, use individual micro data to compare the wages of formal and informal sector employees (e.g., Cox and Edwards, 1997; McIsaac and Rama, 1997; Mondino and Montoya, 2004; and Vargas, 2004), who differ in terms of their exposure to payroll taxes but also in terms of their exposure to other regulations. In contrast to these studies, our analysis explicitly measures tax rates separately from other labor costs. 
The paper is organized as follows. Section 2 illustrates the effects of payroll taxes on wages and employment in situations with and without wage rigidities. Section 3 describes the Colombian institutional background and the changes in mandated payroll taxes in Colombia over the 1980s and 1990s, including the changes in payroll taxes following the Colombian social security reform of 1993 . Section 4 describes the data and presents the results. Section 5 concludes.

\section{Theoretical Effects of Payroll Taxes}

In this section we discuss the impact of payroll taxes on wages and employment under different labor market environments. We begin by showing the effects of payroll taxes in a competitive labor market.

The representative firm chooses employment, $\mathrm{L}_{\mathrm{i}}$, to maximize profits,

$$
\pi_{\mathrm{i}}=\mathrm{pF}\left(\mathrm{L}_{\mathrm{i}}\right)-\mathrm{w}(1+\tau) \mathrm{L}_{\mathrm{i}}
$$

taking the price, p, the wage, w, and the employment level of other firms as given, where $\mathrm{F}\left(\mathrm{L}_{\mathrm{i}}\right)$ is a production function subject to decreasing returns and $\tau$ is the payroll tax firms have to pay out of their wage bill. There are $\mathrm{M}$ identical firms in the economy, so that $\mathrm{L}=M \mathrm{~L}_{\mathrm{i}}$, and from the first-order condition aggregate labor demand is given by,

$$
\mathrm{pF}^{\prime}(\mathrm{L})=\mathrm{w}(1+\tau)
$$

The market-clearing wage and employment levels are set to equate labor demand and supply. Labor supply depends on the wage, and on total work force, N:

$$
\mathrm{L}=[\mathrm{w}(1+\mathrm{b} \tau)]^{\varepsilon} \mathrm{N},
$$

where $\varepsilon$ is the labor supply elasticity and b is the workers' valuation of the benefit (i.e., b =

1 implies a perfect link between benefits and contributions). To see the effect of taxes on 
wages and employment, we first substitute (2) into (1) and take the derivative with respect to the tax rate, which yields,

$$
\operatorname{dlnw} / \mathrm{d} \tau=-[-\varepsilon(1+\tau) / \eta+1] /[-\varepsilon(1+\tau) / \eta+(1+\tau)],
$$

where $\eta$ is the labor demand elasticity. ${ }^{3}$ The effect of payroll taxes on employment is then obtained by taking the derivative of (1) with respect to the tax rate and re-arranging:

$$
\mathrm{dlnL} / \mathrm{d} \tau=\{[\mathrm{dln} w / \mathrm{d} \tau](1+\tau)+1\}(\mathrm{w} / \mathrm{L}),
$$

which equals zero when the tax-benefit link is perfect, $b=1$, when the labor supply is perfectly inelastic, $\varepsilon=0$, or when the labor demand elasticity is perfectly elastic, $\eta \rightarrow \infty{ }^{4}$ This is because in all three cases taxes are fully shifted to workers as lower wages, so there are no disemployment effects. However, as we discussed below, weak linkages in Colombia and other Latin American countries may be one reason to expect "less-than-full shifting” in this continent.

In addition, an elastic labor supply probably also contributes to "less-than-fullshifting” and disemployment effects in the Latin American context. While we know of no estimates of labor supply elasticities, one may suspect the supply of formal labor to be fairly elastic in Latin America as workers can move between formal and informal employment. Our model is consistent with recent evidence on the informal sector as characterized by voluntary entry as a result of inefficiencies in formal sector protections and, more generally, as characterized by large job-to-job flows from and to the formal sector (see, e.g., Maloney (2004, 1999), Maloney and Bosch (2006), Maloney, Goni and Bosch (2007), and Levy (2006)).

\footnotetext{
${ }^{3}$ This expression can also be written to show how the tax-benefit linkage, b, affects shifting. In particular, it can be written as dlnw/d $\tau=-\left\{\left[-\mathrm{pF}^{\prime \prime}(\mathrm{L}) \varepsilon[\mathrm{w}(1+\mathrm{b} \tau)]^{\varepsilon-1} \mathrm{Nb}\right]+1\right\} /\left\{-\mathrm{pF}^{\prime \prime}(\mathrm{L}) \varepsilon[\mathrm{w}(1+\mathrm{b} \tau)]^{\varepsilon-1} \mathrm{~N}(1+\mathrm{b} \tau)+(1+\tau)\right\}$.
} 
Moreover, downward wage rigidities may limit the ability of firms to pass payroll taxes in the form of lower wages, even under the three cases mentioned above. If wage rigidities come from a government mandated minimum wage, $\overline{\mathrm{w}}$, then the firm's problem is as before but the wage is given by the maximum between $\overline{\mathrm{W}}$ and the market-clearing wage, $\mathrm{w}^{*}$, given by $\mathrm{pF}^{\prime}\left(\left[\mathrm{w}^{*}(1+\mathrm{b} \tau)\right]^{\varepsilon} \mathrm{N}\right)=\mathrm{w}^{*}(1+\tau)$. In the case when the minimum wage is binding so that $\overline{\mathrm{w}}>\mathrm{W}^{*}$, and the employment level is given by,

$$
\mathrm{pF}^{\prime}(\mathrm{L})=\overline{\mathrm{w}}(1+\tau)
$$

In this case, there is excess supply of labor and involuntary unemployment or a rise in informal activity. Moreover, the payroll tax always reduces formal employment in this case, since payroll taxes cannot be fully shifted to workers as lower wages. The analyses by Maloney and Núñez (2004), Arango and Pachón (2004), Santamaría (1998) and Bell (1997) all provide evidence showing that minimum wages are likely to be binding in Colombia making it difficult to pass payroll taxes on to workers in the form of lower wages.

\section{Institutional Background}

Colombia, like other Latin American countries, imposed taxes on employers to finance social programs during the middle of the $20^{\text {th }}$ century. In particular, payroll taxes in Colombia finance pensions for the old, disabled, and survivors; health benefits for sickness and maternity; work injury benefits in manufacturing and commerce; family allowances and in-kind transfers for low-income households; and training, paid vacations and mandatory bonuses. ${ }^{5}$ Payroll taxes increased along with increasing benefits between $1 \%$

\footnotetext{
${ }^{4}$ These results also hold when considering an efficiency wage set up (see Kugler and Kugler (2003)). When efficiency wages are paid, the no-shirking condition shifts to counteract the shift of the labor demand function generating no disemployment effects.

${ }^{5}$ In addition, labor legislation requires employers to pay a one month per year worked severance benefit. After the labor market reform of 1990, the standard system of severance payments which required payments
} 
and 2\% in 1982, 1985, 1989 and 1992 and then sharply after 1994 due to the introduction of the 1993 social security reform. Table 1 presents the evolution of mandatory non-wage labor costs starting in 1980. In 1982, a statutory increase in payroll contributions for training increased payroll taxes by $1 \%$. In 1989, the payroll taxes for in-kind transfers to low-income families increased by $1 \%$. The first increase in mandated contributions for old age, disability, and survivor pensions occurred in 1985 with an increase of 2\% (from 4.5\% to 6.5\%). The payroll contributions for pensions increased again in 1992 by $1.5 \%$ and then the social security reform generated large increases in payroll taxes for pensions from 1994 to 1996 of $5.5 \%$ for employers of workers earning less than four minimum wages and of $6.5 \%$ for employers of workers earning more than four minimum wages. There was an initial increase in payroll taxes for pensions of 3.5\% in 1994, an additional increase of $1 \%$ in 1995 and an additional increase of between 1\% and 2\% for high- and low-wage workers, respectively. The social security reform also increased payroll contributions between 1994 and 1996 by 5\% for health benefits for the first time in decades, with a 1\% increase in 1995 and an additional 4\% increase in 1996. The social security reform, therefore, increased payroll taxes for pensions and health by between $10.5 \%$ and $11.5 \%$ in a two-year period, with between 5\% and 6\% of the increase occurring between 1995 and 1996 . This provides a large temporal change in payroll taxes, which is much larger than what is usually observed in high income countries. Our analysis below relies largely on the statutory changes in payroll taxes described here.

at the time of separation was transformed into a system of individual savings accounts (see A. Kugler (1999, 2004, 2005) for a description and analysis of the labor market reform of 1990). Thus, before the labor market reform of 1990, severance payments were fixed costs but, after the reform, they were essentially turned into recurrent labor costs such as payroll taxes. 
As described in the previous section, payroll taxes should not affect employment if payroll taxes are completely passed on to workers as lower wages. This is more likely to happen if the workers' valuations of the services financed by payroll taxes coincide with their cost. However, in Colombia, as in other Latin American countries, the link between payroll taxes and benefits is not exact because many of the benefits financed through payroll taxes are not directly accrued by employees. For example, while all employers pay taxes to finance family allowances, these allowances are received only by workers with low-income families. Also, while all employers pay taxes for training programs, not all firms take advantage of government-provided training programs. For this reason, payroll taxes are less likely to be passed-on to wages in Colombia and other Latin American countries than in developed countries where employer mandated contributions tend to finance direct benefits.

In addition, the social security reform changed the tax-benefit linkage for pensions. On the one hand, the social security reform introduced minimum benefits for workers previously uncovered by the system, weakening the tax-benefit linkage. On the other hand, by introducing a parallel fully-funded system of individual accounts next to the already existing pay-as-you-go (PAYG) system, the reform contributed to strengthen the taxbenefit linkage. Unlike the PAYG system which may not return to the beneficiary the amount contributed into the system, individual accounts guarantee direct benefits to contributors to the system and are likely to have strengthened the tax-benefit linkage during the 1990s. At the same time, trade liberalization increased labor demand elasticities after the reduction of tariffs and quotas in 1991. Fajnzylber and Maloney (2005) find evidence that the introduction of Colombia's trade reform in 1991 increased labor demand elasticities for unskilled workers. As shown in the previous section, an increase in labor demand 
elasticities should increase shifting during the 1990s compared to the 1980s. In the empirical analysis, we indeed find greater shifting and smaller disemployment effects in the 1990s than in the 1980s.

As discussed in the previous section, aside from weak tax-benefit linkages, firms may not be able to pass on their higher payroll taxes to workers in the form of lower wages if minimum wages are binding. Evidence on the minimum wage in Colombia over the period of our study suggests that the minimum wage binds for unskilled workers and may have spillover effects for skilled workers in Colombia. Bell (1997) finds that the 10\% rise in the statutory minimum wage during 1981-87 decreased unskilled employment by between $2 \%$ and $12 \%$. Using data from the rotating household panel starting in 1997, Maloney and Núñez (2004) find an average elasticity of employment with respect to the minimum wage of 0.15 for this later period, which is equivalent to Bell's upper bound. Moreover, Maloney and Núñez (2004) examine the impact of the minimum wage on the wages and employment of workers at different points in the distribution. They find that the minimum wage in Colombia increased wages and reduced employment for those close to the minimum wage but also for those higher up in the distribution because of a numeraire effect. Similarly, Maloney and Núñez (2004) find evidence of binding minimum wages in other Latin American countries, where minimum wages seem to affect not only those at the lower end of the earnings distribution but also higher earnings workers. Arango and Pachón (2004) use repeated cross-sections of the Colombian household surveys from 1984 and 2001 and they find that the minimum wage affects the earnings not only of those close to the minimum wage but also the earnings of those higher up in the distribution, and 
reduces the probability of employment as well as hours worked. ${ }^{6}$ An important implication of these results is that minimum wages generate real rigidities not only for unskilled but also for more skilled workers.

\section{Empirical Analysis}

\subsection{Data Description}

We analyze the impact of payroll taxes on employment and labor costs in Colombia by exploiting the large temporal variation induced by the statutory rise in employer contributions over the 1980s and mostly during the 1990s. Our sample consists of a balanced panel of 235 plants in the formal sector from the Colombian Manufacturing Survey for the 1982-1996 period. ${ }^{7}$ The trends in our sample coincide with the general picture in manufacturing as a whole. Table 2 shows the continuous rise in the real wage and the drop in employment since $1991 .^{8}$

The last two columns of Table 2 also show the trends in GDP growth and GDP per capita growth. Aside from the first two years when GDP growth is low and GDP per capita growth is actually negative, the Colombian economy shows strong growth ranging from 2.0 to 5.8. A potential concern is that our data ends right before the beginning of the strongest recession in almost 60 years. If the beginning of this recession drives both earnings and employment down, then our estimates may be biased towards finding shifting and towards finding disemployment. However, as we show below we are far from finding full shifting,

\footnotetext{
${ }^{6}$ Santamaría (1998) similarly finds evidence of a binding minimum wage in Colombia.

${ }^{7}$ The Colombian Manufacturing Survey only samples plants with more than 10 employees. All plants in our sample report positive payroll taxes, thus, implying compliance with labor legislation (at least for some of their employees) and participation in the formal sector. We focus on the impact of payroll taxes on the internal margin using a balanced panel, because spurious entry and exit resulting from changes in the survey methodology over the 1990s makes it more difficult to estimate effects on the external margin. In this sense, we probably provide a lower bound on the impact of payroll taxes on formal employment.

${ }^{8}$ Wages are deflated by a sector-specific producer price index.
} 
as our estimates suggest that only between $14 \%$ and $23 \%$ of the taxes are passed on as lower wages. In addition, to address this issue, below we pick pairs of years with changes in tax rates that look similar in terms of growth.

Table 2 also shows the trend in average tax rates over the sample period. The average tax rate is calculated as the ratio of total contributions to the wage bill. The table shows the upward trend over the 1980s, a drop in the early 1990s and the sharp rise in tax rates starting in 1993 coinciding with the statutory changes in payroll taxes reported in Table 1. An advantage of our data is that, while the changes in payroll taxes coincide with the statutory changes, we can rely on actual information of the payroll tax cost rather than having to impute the average cost to plants.

The data shows that most of the variation of changes in tax rates corresponds to statutory changes in taxes over time. Figures 1 to 4 show tax changes for pairs of years during the 1980s. Figure 1 shows the distribution of changes in tax rates between 1984 and 1985. The figure shows that the mean of the distribution of changes in taxes is $1.95 \%$ or slightly under the $2 \%$ statutory change in taxes. Moreover, the changes above and below the $1.95 \%$ change are close to being normally distributed with $75 \%$ of the plants having tax rate changes between $1.75 \%$ and $2.15 \%$. Similarly, Figure 2 shows the distribution of changes in tax rates in between 1988 and 1989, which has a mean of 0.995\% or virtually the $1 \%$ statutory change reported in Table 1 . In addition, the changes in tax rates are tightly distributed around the $0.995 \%$ with $80 \%$ of the plants having tax rate changes between 0.87\% and 1.12\%. By contrast Figures 3 and 4 show the changes in tax rates between 1983 and 1984 and between 1989 and 1990, when there were no statutory changes in taxes. The changes in taxes for these years are indeed centered at zero and there are very small changes above and below 0 ranging from $-0.02 \%$ to $0.02 \%$. 
Figures 5 and 6 show the distribution of changes in tax rates between 1993 and 1994 and between 1995 and 1996. The mean of the changes in tax rates between 1993 and 1994 in Figure 5 is $4 \%$. The distribution is close to normal with $95 \%$ of the plants tax changes ranging between $3.98 \%$ and $4.02 \%$. Figure 6 shows mean changes in taxes of $5.8 \%$, while the statutory changes were between $5.5 \%$ and $6 \%$. This distribution also has dispersion above and below the mean tax change; with about $75 \%$ of the plants have tax changes ranging from $5.2 \%$ to $6.4 \%$.

These distributions of changes in tax rates show that the data closely captures the statutory changes in tax rates that took place in Colombia over the 1980s and 1990s. In addition, the distributions show that cross-sectional variation of changes in tax rates across plants is generally small. Perhaps more importantly, when the measured tax rate changes deviate from the statutory change, these changes in taxes are both above and below the statutory change. The fact that there are changes above the statutory changes suggests that these deviations do not simply reflect plants' decisions to use temporary contracts or to hire underground as a way to reduce their tax payments. Likewise, the deviations in Figure 6 are unlikely to simply reflect plants’ move towards hiring more low earnings workers after the statutory change in 1996 as a way to avoid higher taxes for workers earning more than four times the minimum wage, since some of the changes are actually greater than the statutory changes. ${ }^{9}$

\footnotetext{
${ }^{9}$ Many of the actual changes are above the statutory changes and plants would not generally make adjustments that increase their payroll costs. However, if plants adjusted to increases in payroll taxes by hiring more temporary workers as a way to avoid these costs, then the bias would be against finding shifting. Similarly, if plants adjusted to the differential increase in taxes for high earnings workers by hiring more low earnings workers, this would generate a bias against finding pass-through. On the other hand, it is not clear what the sign would be on the bias or if there should be a bias for the employment results as a result of these adjustments.
} 
One reason why changes in tax rates may be both above and below the statutory changes is the fact that employers' work injury contributions depend on the degree of risk, where the payroll taxes range from $0.35 \%$ to $8.7 \%$ (see Table 1 ) depending on the risk of injury at the plant. Thus, increases or decreases in injury risk at a plant would affect the payroll tax contributions at that plant over time. Deviations of changes in tax rates from statutory changes due to differences in the nature of the risk pool would generate a valid source of identification to examine the impact of taxes on wages and employment.

However, another reason why actual changes in tax rates may be above or below the statutory changes is because of measurement error due to misreporting or recording errors in the tax and wage bills. Classical measurement error in the tax bill will bias the effects of payroll taxes on wages and employment towards zero, while measurement error in the wage bill will bias the results towards a finding of shifting to wages and the effect of payroll taxes on employment towards zero. We follow Gruber's (1997) identification strategy by assuming that there is a dimension of variation along which the true tax rate varies, but the spurious components of the measured tax rate do not. First, we assume that plants systematically overstate or understate the tax rate so that fixed plant-specific measurement error is absorbed by plant effects. We also assume that any spurious time-varying component of tax rates follows linear sector-specific or plant-specific trends. These approaches also help to control for omitted variables correlated with tax rates. For example, these control for the possibility that systematically high wage workplaces are also the ones with the lowest fraction of uncovered payroll or the ones with the highest risk of accidents, if the fact that a plant is high wage is mostly fixed over time or follows sectorspecific or plant-specific trends. 


\subsection{Results}

Table 2 shows that the social security reform of 1993 coincided with an expansion right before a recession. Following Gruber (1997), we therefore restrict the analysis to years at similar points in the cycle. For the 1980s, we use 1983-1984 and 1989-90 for pairs of expansionary years and 1984-85 and 1988-89 for pairs of recessionary years. For the 1990s, we use 1993-94 and 1995-96 as pairs of years at similar points in the business cycle before and after the full implementation of the social security reform.

The post-1992 data, for which we cannot separate production and non-production workers are used to estimate:

$$
\begin{array}{r}
\Delta \log \left(\mathrm{W}_{\mathrm{ijt}} / \mathrm{E}_{\mathrm{ijt}}\right)=\alpha_{1}+\beta_{1} \Delta \tau_{\mathrm{ijt}}+\theta_{\mathrm{t}}+\mathrm{u}_{\mathrm{ijt}}, \\
\Delta \log \left(\mathrm{E}_{\mathrm{ijt}}\right)=\alpha_{2}+\beta_{2} \Delta \tau_{\mathrm{ijt}}+\theta_{\mathrm{t}}+\mathrm{e}_{\mathrm{ijt}},
\end{array}
$$

where the ratio of total payroll taxes, $\mathrm{T}_{\mathrm{ijt}}$, over total wages, $\mathrm{W}_{\mathrm{ijt}}$, gives the tax rate for plant $\mathrm{i}$ in sector $\mathrm{j}$ at time $\mathrm{t}$, i.e., $\tau_{\mathrm{ijt}}=\left(\mathrm{T}_{\mathrm{ijt}} / \mathrm{W}_{\mathrm{ijt}}\right)$, and where $\mathrm{E}_{\mathrm{ijt}}$ is total employment. These regressions include year effects, $\theta_{t}$, while differencing eliminates plant effects. Since the regressions are estimated in first differences, the identifying information is actually coming from the changes in the tax rate across years shown in Figures 1-6. Moreover, the identifying assumption is that omitted variables are absorbed by year, sector, and plant controls. We also add sector effects, $\gamma_{\mathrm{j}}$, to the specifications in differences to control for sector-specific trends:

$$
\begin{array}{r}
\Delta \log \left(\mathrm{W}_{\mathrm{ijt}} / \mathrm{E}_{\mathrm{ijt}}\right)=\alpha_{3}+\beta_{3} \Delta \tau_{\mathrm{ijt}}+\theta_{\mathrm{t}}+\gamma_{\mathrm{j}}+\mathrm{u}_{\mathrm{ijt}}, \\
\Delta \log \left(\mathrm{E}_{\mathrm{ijt}}\right)=\alpha_{4}+\beta_{4} \Delta \tau_{\mathrm{ijt}}+\theta_{\mathrm{t}}+\gamma_{\mathrm{j}}+\mathrm{e}_{\mathrm{ijt} .}
\end{array}
$$


Finally, we estimate models that control for plant-specific trends by adding plant effects, $\varphi_{\mathrm{i}}$, to the specification in differences:

$$
\begin{array}{r}
\Delta \log \left(\mathrm{W}_{\mathrm{ijt}} / \mathrm{E}_{\mathrm{ijt}}\right)=\alpha_{5}+\beta_{5} \Delta \tau_{\mathrm{ijt}}+\theta_{\mathrm{t}}+\varphi_{\mathrm{i}}+\mathrm{u}_{\mathrm{ijt}}, \\
\Delta \log \left(\mathrm{E}_{\mathrm{ijt}}\right)=\alpha_{6}+\beta_{6} \Delta \tau_{\mathrm{ijt}}+\theta_{\mathrm{t}}+\varphi_{\mathrm{i}}+\mathrm{e}_{\mathrm{ijt}} .
\end{array}
$$

In addition to pooled analyses, that group all types of workers, pre-1992 data are used to estimate models for production and non-production workers separately, i.e., fully saturated models of (1) and (2). We estimate these differences regressions with and without sector effects. The specifications with sector effects allow the true variation in taxes to be along the plant-year and the plant-year-worker type dimensions controlling for sector-specific trends for each worker type, i.e., fully saturated versions of models (3) and (4). Again, we add plant effects as in the pooled models, so we estimate fully saturated versions of (5) and (6) for production and non-production workers.

While the data for the 1990s do not disaggregate production and non-production workers, the large temporal change in payroll taxes occurred during this time period after the social security reform. Columns (1) and (2) in Table 3 report estimates of the impact of payroll taxes on the wages and employment of production and non-production workers during the 1990s. In particular, the first two rows report differences results with and without sector effects estimated using equations (1)-(4). The results without controlling for sector-specific effects suggest that an increase in payroll taxes of a similar magnitude to the increase that followed the 1993 social security reform (i.e., a 10\% increase) reduces wages by $1.42 \%$ and employment by $2.73 \%$. Controlling for sector-specific trends shows larger effects on both wages and employment, suggesting measurement error on the tax rate rather 
than on wages. ${ }^{10}$ In particular, the results with sector-specific trends suggest that a $10 \%$ increase in the payroll tax rate reduces wages by $1.87 \%$ and employment by $3.05 \%$. The results controlling for plant-specific trends in the third row show even larger shifting and disemployment effects. In particular, a 10\% increase in the payroll tax rate reduces wages by $2.35 \%$ and employment by $3.84 \%$. These wage and employment effects are also in line with those found by Heckman and Pagés (2004) using panel data for Latin American countries. They find that a $10 \%$ increase in social security contributions reduces wages and employment in Latin America by 3.6\% and 4.5\%, respectively.

The rest of the columns in Table 3 show the results for the pre-1992 years, pooling together production and non-production workers. In particular, the table reports results with and without controls for sector-specific trends estimated using equations (1)-(2) and (3)-(4) as well as results with controls for plant-specific trends, i.e., equations (5)-(6). The results from the differences specification, which controls for sector-specific trends, show partial shifting of payroll taxes to wages and negative effects on employment. ${ }^{11}$ In particular, the results for both the expansion and recession pre-1992 years show that a 10\% increase in payroll taxes during the expansionary years of the 1980s decreases wages by $1.75 \%$ and employment by $2.1 \%$. However, when we control for plant-specific effects, shifting becomes smaller and disemployment effects larger during recession years. The results for the expansionary pre-1992 years, which control for plant-specific trends, suggest that a $10 \%$ increase in payroll tax rates reduces average wages by $2.27 \%$ and employment by close to $5 \%$. By contrast, the results for the recession pre-1992 years suggest that a $10 \%$

\footnotetext{
${ }^{10}$ We find that the sector effects are significantly different from each other. The F-statistics of the test of a null of equality across sectors in the wage and employment regressions using data on the 1990s are 0.027 and 0.011 respectively.

11 The tests of equality of sector effects for the wage and employment regressions using recessionary year data yield F-statistics of 0.048 and 0.026. In expansion years, the corresponding F-statistics are 0.019 and 0.039.
} 
rise in payroll taxes reduces employment by $5 \%$ but lowers wages by only $1.37 \%$ suggesting less shifting during recessions.

The results for the 1980s can be compared with the results for the 1990s to check whether the change in tax-benefit linkages generated by the social security reform affected the effects of payroll taxes on shifting and employment. As discussed above, the social security reform weakened the tax-benefit linkage due to the introduction of minimum pensions. At the same time, the movement from a PAYG system to a fully-funded system probably strengthened the tax-benefit linkage. Results with plant-effects suggest that shifting increased after the introduction of the reform, suggesting the movement to a fullyfunded system was probably more important than the introduction of minimum pensions. Moreover, greater shifting could also be explained by an increase in labor demand elasticities during this period. As indicated above, Fajnzylber and Maloney (2005) indeed find evidence that labor demand elasticities increased for blue collar workers in Colombia after trade was liberalized in 1991. Consistent with more shifting, the results with planteffects also suggest less disemployment after the introduction of the trade and social security reforms in the 1990s.

Table 4 reports results for the pre-1992 years, for which it is possible to separate production and non-production workers. In particular, the table reports results of specifications estimated using equations (1) and (2) and of specifications controlling for sector-specific and plant-specific trends estimated using equations (3)-(6). Consistent with minimum wages binding more for production than for non-production workers, these results show less shifting to wages for production than for non-production workers. Moreover, consistent with less shifting for production workers, the results indicate greater negative effects of payroll taxes on the employment of production than of non-production 
workers. Columns (1)-(4) report results using data for the expansionary pre-1992 years. Results from specifications which control for sector-specific trends suggest that a $10 \%$ increase in payroll taxes reduce production wages by less than $1 \%$ but reduce nonproduction wages by $2.68 \%$, and these are significantly different from each other at the $1 \%$ level. ${ }^{12}$ Consistent with less shifting for production workers, these results also suggest that a $10 \%$ increase in payroll taxes reduces employment for production workers by close to $4 \%$ and for non-production workers by close to $2 \%$, where the difference between production and non-production workers is significant at the $2 \%$ level.

Results controlling for plant-specific trends rather than sector-specific trends show greater shifting and bigger disemployment effects for both groups, but continue to show greater shifting for non-production workers. These results suggest that a $10 \%$ increase in payroll taxes reduces the production wages by $1.39 \%$ and non-production wages by 2.89 (the p-value of the difference in wage effects between production and non-production is 0.058), while reducing employment of production workers by $5.49 \%$ and employment of non-production workers by $4.9 \%$, though the employment effects for production and nonproduction workers are not significantly different from each other.

Columns (5)-(8) in Table 4 report similar results for the recessionary pre-1992 years. These estimates generally show less shifting and larger disemployment effects for production than for non-production workers as a result of higher payroll taxes. Yet, the results also show more shifting for production workers and less shifting for non-production workers during recessionary years than expansionary years. Non-production workers, who are less likely to be laid-off during recessions, may be less willing to take wage cuts.

\footnotetext{
12 Tests of equality of the sector effects in the production and the non-production wage regressions have Fstatistics of 0.014 and 0.041 , respectively. For the employment regressions, the statistics are 0.034 and 0.022 .
} 
By contrast, production workers would be more willing to take wage cuts given the higher threat of layoffs for them. The specification controlling for sector-specific trends suggest that a $10 \%$ increase in payroll taxes reduces the wages and employment of production workers by $1.1 \%$ and $3.25 \%$ and reduces the wages and employment of nonproduction workers by $1.9 \%$ and $1.97 \% .{ }^{13}$ As for the expansionary years, controlling for plant-specific trends increases shifting and disemployment effects for both groups, though shifting continues to be greater for non-production workers. In particular, the results show that a $10 \%$ increase in payroll taxes reduce production wages by $1.46 \%$ and non-production wages by $2.75 \%$, while reducing production employment by $5.14 \%$ and non-production employment by $4.38 \%$.

However, shifting coefficients between production and non-production workers during recession are not significantly different from each other, probably because nonproduction workers are less likely to adjust wages downwards during recessions while production workers are more likely to accept bigger wage cuts during recessions to avoid losing their jobs. On the other hand, the results for production and non-production workers during expansionary years suggest that policies aimed at boosting the relative demand of production workers by reducing payroll taxes for this group of workers are likely to be effective in terms of increasing formal employment for less skilled workers.

\section{Conclusion}

Payroll taxes and other regulations are often blamed for reducing formal employment in developing countries. In theory, however, the employment consequences of

\footnotetext{
${ }^{13}$ For the wage regressions, tests of equality of sector effects for production and non-production workers yield F-statistics of 0.000 and 0.002 , respectively. For the employment regressions, the corresponding F-statistics are 0.008 and 0.032 .
} 
payroll taxes depend on the extent to which they can be passed-on to workers in the form of lower wages. In this paper, we exploit a very large increase in payroll taxes following the social security reform in Colombia in 1993 to study the impact of these taxes on employment and wages. In terms of identification in our estimation, an advantage of this reform is that the increase in payroll taxes was much larger than it is typically observed in developed countries and even in other developing countries. Moreover, unlike other reforms in the region, because the Colombian reform increased (rather than decreased) payroll taxes, we can study whether payroll taxes are passed-on to workers as lower wages.

Our estimates suggest that only about one fifth of the increase in taxes was shifted to workers as lower wages. This is roughly in line with Heckman and Pagés’ (2004) results which show a one-third shifting of payroll taxes using cross-sectional data for Latin America. Complementing the partial shifting result, our findings show that a $10 \%$ increase in payroll taxes reduces formal employment by between $4 \%$ and $5 \%$. In addition, there appears to be less shifting and greater negative effects of payroll taxes on formal employment for production than for non-production workers, especially during expansionary years. These results suggest that tax subsidies for less skilled workers may be particularly effective, especially if applied to indirect benefits and during expansionary years.

A natural avenue for future research in the context of less developed countries would be to study the labor supply consequences of payroll taxes and, in particular, to study whether workers displaced from formal employment following the rise in payroll taxes move into unemployment or informal sector employment. 


\section{References}

Arango, Carlos and Angelica Pachón. 2004. "Minimum Wages in Colombia: Holding the Middle with a Bite,” Borradores de Economia 001601, Banco de la República, Bogotá.

Bell, Linda. 1997. "The Impact of Minimum Wages in Colombia," Journal of Labor Economics, Vol. 15, No. 3, pp. S102-S135.

Blau, Francine and Lawrence Kahn. 1999. "Labor Market Institutions and Economic Performance.” In Orley Ashenfelter and David Card, eds., Handbook of Labor Economics, Volume 3. New York: Elsevier, pp, 1399-1461.

Cox-Edwards, Alejandra and Sebastian Edwards. 2002. "Social Security Reform and Labor Markets: The Case of Chile,” Economic Development and Cultural Change, Vol. 50, No. 3, pp. 465-489.

Fajnzylber, Pablo and William Maloney. 2005. "Labor Demand and Trade Reform in Latin America,” Journal of International Economics, Vol. 66, No. 2, pp. 423-446.

Gill, Indermit, Truman Packard and Juan Yermo. 2005. Keeping the Promise of Social Security in Latin America. Washington, D.C.: The World Bank.

Gordon, Robert. 1972. "Wage-Price Controls and the Shifting Phillips Curve,” Brookings Papers on Economic Activity, Vol. 2, pp. 385-421.

Gruber, Jonathan. 1997. "The Incidence of Payroll Taxation: Evidence from Chile," Journal of Labor Economics, Vol. 15, No. 3, pp. S72-S101.

Gruber, Jonathan. 1994. "The Incidence of Mandated Maternity Benefits,” American Economic Review, Vol. 84, No. 3, pp. 622-41.

Gruber, Jonathan and Alan Krueger. 1991. "The Incidence of Mandated EmployerProvided Insurance: Lessons from Workers' Compensation Insurance.” In David Bradford, ed., Tax Policy and the Economy. Cambridge, Mass.: MIT Press, pp. 111-44.

Hamermesh, Daniel. 2004. "Labor Demand in Latin America and the Caribbean: What Does It Tell Us?” In James Heckman and Carmen Pagés, eds., Law and Employment: Lessons from Latin America and the Caribbean. Chicago: Chicago University Press/NBER, pp. 553-562.

Hamermesh, Daniel. 1993. Labor Demand. Princeton: Princeton University Press.

Hamermesh, Daniel. 1979. "New Estimates of the Incidence of the Payroll Tax," Southern Economic Journal, Vol. 45, pp. 1208-19. 
Heckman, James and Carmen Pagés. 2004. “Introduction.” In James Heckman and Carmen Pagés, eds., Law and Employment: Lessons from Latin America and the Caribbean. Chicago: Chicago University Press/NBER, pp. 1-108.

Kaestner, Robert. 1996. "The Effect of Government-Mandated Benefits on Youth Employment,” Industrial and Labor Relations Review, Vol. 50, No. 1, pp. 122-142.

Kugler, Adriana. 2005. "Wage-Shifting Effects of Severance Payments Savings Accounts in Colombia," Journal of Public Economics, Vol. 89, No. 2-3, pp. 487-500.

Kugler, Adriana. 2004. "The Effect of Job Security Provision Regulations on Labor Market Flexibility: Evidence from the Colombian Labor Market Reform.” In James Heckman and Carmen Pagés, eds., Law and Employment: Lessons from Latin America and the Caribbean. Chicago: Chicago University Press/NBER, pp. 183-228.

Kugler, Adriana. 1999. "The Impact of Firing Costs on Turnover and Unemployment: Evidence from the Colombian Labour Market Reform,” International Tax and Public Finance, Vol. 6, No. 3, pp. 389-410.

Levy, Santiago. 2006. "Social Security Reform in Mexico: For Whom?” World Bank Conference on Equity and Competitiveness in Mexico, Mexico City.

Maloney, William. 2004. “Informality Revisited,” World Development, Vol. 32, No. 7, pp. 1159-1178.

Maloney, William. 1999. "Does Informality Imply Segmentation in Urban Labor Markets? Evidence from Sectoral Transitions in Mexico," World Bank Economic Review, Vol. 13, No. 2, pp. 275-302.

Maloney, William and Mariano Bosch. 2006. "Gross Worker Flows in the Presence of Informal Markets: the Mexican Experience 1987-2002,” World Bank Research Working Paper No. 3883.

Maloney, William, Edwin Goni and Mariano Bosch. 2007. "The Determinants of Rising Informality in Brazil: Evidence from Gross Worker Flows,” World Bank Research Working Paper No. 4375.

Maloney, William and Jairo Núñez. 2004. "Minimum Wages in Latin America.” In James Heckman and Carmen Pagés, eds., Law and Employment: Lessons from Latin America and the Caribbean. Chicago: Chicago University Press/NBER, pp.109-130.

McIsaac, Donna and Martin Rama. 1997. "Determinants of Hourly Earnings in Ecuador: The Role of Labor Market Regulations," Journal of Labor Economics, Vol. 15, No. 3, pp. S136-S165. 
Mondino, Guillermo and Silvia Montoya. 2004. “The Effects of Labor Market Regulations on Employment Decisions by Firms.” In James Heckman and Carmen Pagés, eds., Law and Employment: Lessons from Latin America and the Caribbean. Chicago: Chicago University Press/NBER, pp. 351-399.

Nickell, Stephen and Richard Layard. 1999. "Labor Market Institutions and Economic Performance.” In Orley Ashenfelter and David Card, eds., Handbook of Labor Economics, Volume 3. New York: Elsevier, pp, 3029-84.

OECD. 1995. OECD Jobs Study: Taxation, Employment, and Unemployment. Paris: OECD.

Santamaría, Mauricio. 1998. "Nonparametric Density Estimation and Regression: An Application to the Study of Income Inequality and Poverty in Colombia," Doctoral Dissertation, Georgetown University, Washington DC.

Shapiro, Carl and Joseph Stiglitz. 1984. "Equilibrium Unemployment as a Worker Discipline Device,” American Economic Review, Vol. 74, No. 3, pp. 433-444.

Vargas, Andrés. 2004. "The Effect of Social Security Contributions on Wages: The Colombian Experience,” Unpublished paper, University of Texas at Austin.

Vroman, Wayne. 1974. "Employer Payroll Taxes and Money Wage Behavior," Applied Economics, Vol. 6, No. 3, pp. 189-204. 
Table 1: Composition of Payroll Taxes, 1980-1996

\begin{tabular}{|c|c|c|c|c|c|c|c|c|}
\hline Payroll Tax & 1980 & 1982 & 1985 & 1989 & 1992 & 1994 & 1995 & 1996 \\
\hline Pensions & $4.5 \%$ & $4.5 \%$ & $6.5 \%$ & $6.5 \%$ & $8.0 \%$ & $11.5 \%$ & $12.5 \%$ & $\begin{array}{c}13.5 \%- \\
14.5 \%\end{array}$ \\
\hline Health & $7.0 \%$ & $7.0 \%$ & $7.0 \%$ & $7.0 \%$ & $7.0 \%$ & $7.0 \%$ & $8.0 \%$ & $12.0 \%$ \\
\hline Work Injury & $\begin{array}{r}0.35 \% \\
8.7 \%\end{array}$ & $\begin{array}{c}0.35 \%- \\
8.7 \%\end{array}$ & $\begin{array}{c}0.35 \%- \\
8.7 \%\end{array}$ & $\begin{array}{c}0.35 \%- \\
8.7 \%\end{array}$ & $\begin{array}{c}0.35 \%- \\
8.7 \%\end{array}$ & $\begin{array}{c}0.35 \%- \\
8.7 \%\end{array}$ & $\begin{array}{c}0.35 \%- \\
8.7 \%\end{array}$ & $\begin{array}{c}0.35 \%- \\
8.7 \%\end{array}$ \\
\hline $\begin{array}{l}\text { In-kind } \\
\text { Transfers }\end{array}$ & $2.0 \%$ & $2.0 \%$ & $2.0 \%$ & $3.0 \%$ & $3.0 \%$ & $3.0 \%$ & $3.0 \%$ & $3.0 \%$ \\
\hline $\begin{array}{l}\text { Family } \\
\text { Allowances }\end{array}$ & $4.0 \%$ & $4.0 \%$ & $4.0 \%$ & $4.0 \%$ & $4.0 \%$ & $4.0 \%$ & $4.0 \%$ & $4.0 \%$ \\
\hline Training & $1.0 \%$ & $2.0 \%$ & $2.0 \%$ & $2.0 \%$ & $2.0 \%$ & $2.0 \%$ & $2.0 \%$ & $2.0 \%$ \\
\hline $\begin{array}{l}\text { Paid } \\
\text { Vacations }\end{array}$ & $4.15 \%$ & $4.15 \%$ & $4.15 \%$ & $4.15 \%$ & $4.15 \%$ & $4.15 \%$ & $4.15 \%$ & $4.15 \%$ \\
\hline $\begin{array}{l}\text { Mandatory } \\
\text { Bonuses }\end{array}$ & $4.15 \%$ & $4.15 \%$ & $4.15 \%$ & $4.15 \%$ & $4.15 \%$ & $4.15 \%$ & $4.15 \%$ & $4.15 \%$ \\
\hline $\begin{array}{l}\text { Severance } \\
\text { Pay }\end{array}$ & $8.33 \%$ & $8.33 \%$ & $8.33 \%$ & $8.33 \%$ & $8.33 \%$ & $8.33 \%$ & $8.33 \%$ & $8.33 \%$ \\
\hline Total & $\begin{array}{c}35.48 \%- \\
43.78 \%\end{array}$ & $\begin{array}{c}36.48 \% \text { - } \\
44.83 \%\end{array}$ & $\begin{array}{c}38.48 \% \text { - } \\
46.83 \%\end{array}$ & $\begin{array}{c}39.43 \%- \\
47.83 \%\end{array}$ & $\begin{array}{c}40.98 \% \text { - } \\
48.33 \%\end{array}$ & $\begin{array}{c}44.48 \% \text { - } \\
52.83 \%\end{array}$ & $\begin{array}{c}46.48 \% \text { - } \\
54.83 \%\end{array}$ & $\begin{array}{c}51.48 \% \text { - } \\
60.83 \%\end{array}$ \\
\hline
\end{tabular}

Notes: Work injury compensation taxes only apply to workers in manufacturing and commerce and depend on the degree of risk faced by the firm. In 1996, payroll tax contributions for pensions increased from $12.5 \%$ to $13.5 \%$ for employers of workers earning less than four minimum wages and to $14.5 \%$ for employers of workers earning more than four minimum wages. The paid vacations and bonuses contributions reported in the table are the minimum paid vacations and bonuses mandated by law, but firms' payroll contributions for paid vacations and bonuses may vary because some firms offer their employees paid vacations and bonuses above these minimum levels. Severance pay were paid upon separation prior to the labor market reform of 1990, but after the reform they were turned into payroll taxes deposited in an individual savings accounts on a monthly basis. 
Table 2: Time Series Data on the Labor Market

\begin{tabular}{|c|c|c|c|c|c|c|}
\hline Year & $\mathrm{N}$ & Average Tax Rate & $\begin{array}{c}\text { Average Log Real } \\
\text { Wage }\end{array}$ & $\begin{array}{l}\text { Average Log } \\
\text { Total } \\
\text { Employment }\end{array}$ & $\begin{array}{c}\text { GDP } \\
\text { Growth (\%) }\end{array}$ & $\begin{array}{c}\text { Per Capita } \\
\text { GDP Growth } \\
(\%)\end{array}$ \\
\hline 1982 & 235 & $\begin{array}{c}0.4711 \\
(0.2196)\end{array}$ & $\begin{array}{c}4.9201 \\
(0.4049)\end{array}$ & $\begin{array}{c}3.7782 \\
(1.0868)\end{array}$ & 0.9 & -1.3 \\
\hline 1983 & 235 & $\begin{array}{c}0.4816 \\
(0.2291)\end{array}$ & $\begin{array}{c}5.4654 \\
(0.4149)\end{array}$ & $\begin{array}{c}3.7787 \\
(1.0762)\end{array}$ & 1.6 & -0.6 \\
\hline 1984 & 235 & $\begin{array}{c}0.4877 \\
(0.2204)\end{array}$ & $\begin{array}{c}5.4843 \\
(0.4016)\end{array}$ & $\begin{array}{l}3.8173 \\
(1.053)\end{array}$ & 3.4 & 1.3 \\
\hline 1985 & 235 & $\begin{array}{c}0.4845 \\
(0.2113)\end{array}$ & $\begin{array}{c}5.6176 \\
(0.3817)\end{array}$ & $\begin{array}{c}3.8084 \\
(1.0204)\end{array}$ & 3.1 & 1.1 \\
\hline 1986 & 235 & $\begin{array}{c}0.5051 \\
(0.2229)\end{array}$ & $\begin{array}{c}5.7898 \\
(0.3924)\end{array}$ & $\begin{array}{l}3.8217 \\
(0.988)\end{array}$ & 5.8 & 3.8 \\
\hline 1987 & 235 & $\begin{array}{c}0.5363 \\
(0.2104)\end{array}$ & $\begin{array}{l}5.9577 \\
(0.378)\end{array}$ & $\begin{array}{c}3.8486 \\
(1.01684)\end{array}$ & 5.4 & 3.4 \\
\hline 1988 & 235 & $\begin{array}{c}0.546 \\
(0.212)\end{array}$ & $\begin{array}{c}6.0238 \\
(0.4123)\end{array}$ & $\begin{array}{c}3.8468 \\
(1.0269)\end{array}$ & 4.1 & 2.1 \\
\hline 1989 & 235 & $\begin{array}{c}0.5728 \\
(0.2429)\end{array}$ & $\begin{array}{c}6.4237 \\
(0.381)\end{array}$ & $\begin{array}{c}3.8597 \\
(1.0664)\end{array}$ & 3.4 & 1.5 \\
\hline 1990 & 235 & $\begin{array}{c}0.5787 \\
(0.2418)\end{array}$ & $\begin{array}{c}6.5145 \\
(0.3837)\end{array}$ & $\begin{array}{c}3.8517 \\
(1.0924)\end{array}$ & 4.3 & 2.4 \\
\hline 1991 & 235 & $\begin{array}{c}0.5839 \\
(0.2611)\end{array}$ & $\begin{array}{c}7.0361 \\
(0.3941)\end{array}$ & $\begin{array}{c}3.8807 \\
(1.1227)\end{array}$ & 2.0 & 0.2 \\
\hline 1992 & 235 & $\begin{array}{l}0.4967 \\
(0.212)\end{array}$ & $\begin{array}{c}7.5365 \\
(0.4676)\end{array}$ & $\begin{array}{c}3.4766 \\
(1.3396)\end{array}$ & 4.0 & 2.2 \\
\hline 1993 & 235 & $\begin{array}{c}0.5494 \\
(0.1979)\end{array}$ & $\begin{array}{c}8.1597 \\
(0.3983)\end{array}$ & $\begin{array}{c}4.0117 \\
(1.1172)\end{array}$ & 5.4 & 3.6 \\
\hline 1994 & 235 & $\begin{array}{c}0.539 \\
(0.1697)\end{array}$ & $\begin{array}{c}7.8514 \\
(0.4332)\end{array}$ & $\begin{array}{c}3.4537 \\
(1.2439)\end{array}$ & 5.8 & 4.0 \\
\hline 1995 & 235 & $\begin{array}{c}0.5923 \\
(0.1946)\end{array}$ & $\begin{array}{l}8.3265 \\
(0.463)\end{array}$ & $\begin{array}{c}3.4469 \\
(1.2491)\end{array}$ & 5.8 & 3.9 \\
\hline 1996 & 235 & $\begin{array}{c}0.5979 \\
(0.1847) \\
\end{array}$ & $\begin{array}{r}8.5849 \\
(0.4645) \\
\end{array}$ & $\begin{array}{c}3.4089 \\
(1.2368) \\
\end{array}$ & 2.0 & 0.2 \\
\hline
\end{tabular}

Notes: Tax rates are the employer contributions as a fraction of wages. Real wages are total wages over number of workers deflated using PPI. Standard deviations are in parenthesis. Data on GDP growth and per capita GDP growth were provided by DANE. 
Table 3: Estimates of the Effects of Payroll Taxes

on Wages and Employment, All Workers

\begin{tabular}{|c|c|c|c|c|c|c|c|}
\hline \multirow[b]{2}{*}{$\begin{array}{l}\text { Sector } \\
\text { Trends }\end{array}$} & \multirow[b]{2}{*}{$\begin{array}{c}\text { Plant } \\
\text { Trends }\end{array}$} & \multicolumn{2}{|c|}{ 1990s, Expansion Years } & \multicolumn{2}{|c|}{ 1980s, Expansion Years } & \multicolumn{2}{|c|}{ 1980s, Recession Years } \\
\hline & & $\begin{array}{c}\text { Wages } \\
(1)\end{array}$ & $\begin{array}{c}\text { Employment } \\
(2)\end{array}$ & $\begin{array}{c}\text { Wages } \\
(3)\end{array}$ & $\begin{array}{c}\text { Employment } \\
(4)\end{array}$ & $\begin{array}{c}\text { Wages } \\
(5)\end{array}$ & $\begin{array}{c}\text { Employment } \\
(6)\end{array}$ \\
\hline No & No & $\begin{array}{l}-0.1422 \\
(0.0112)\end{array}$ & $\begin{array}{l}-0.2725 \\
(0.0837)\end{array}$ & $\begin{array}{c}-0.1685 \\
(0.0602)\end{array}$ & $\begin{array}{l}-0.1925 \\
(0.0389)\end{array}$ & $\begin{array}{c}-0.1717 \\
(0.0691)\end{array}$ & $\begin{array}{l}-0.1638 \\
(0.0847)\end{array}$ \\
\hline Yes & No & $\begin{array}{l}-0.1869 \\
(0.0128)\end{array}$ & $\begin{array}{l}-0.3047 \\
(0.0933)\end{array}$ & $\begin{array}{l}-0.1746 \\
(0.0318)\end{array}$ & $\begin{array}{c}-0.2093 \\
(0.0343)\end{array}$ & $\begin{array}{c}-0.1752 \\
(0.0863)\end{array}$ & $\begin{array}{l}-0.2086 \\
(0.0704)\end{array}$ \\
\hline No & Yes & $\begin{array}{c}-0.2346 \\
(0.0883)\end{array}$ & $\begin{array}{l}-0.3841 \\
(0.1572)\end{array}$ & $\begin{array}{c}-0.2274 \\
(0.0435)\end{array}$ & $\begin{array}{l}-0.5031 \\
(0.0928)\end{array}$ & $\begin{array}{l}-0.1369 \\
(0.0625)\end{array}$ & $\begin{array}{l}-0.4983 \\
(0.0471)\end{array}$ \\
\hline
\end{tabular}

Notes: The table reports results from regressions of first-differences specifications without sector and year effects, with sector effects and with firm effects using data for 1993-94 and 1995-96 in Columns (1) and (2), using data for 1983-84 and 1989-90 for the expansion years in Columns (3) and (4), and using data for 1984-85 and 1988-89 for the recession years in Columns (5) and (6). The specifications using pooled data for the 1980s include a production dummy. Standard errors are in parenthesis. 


\section{Table 4: Estimates of Effects of Payroll Taxes on Wages and Employment during the 1980s, Production and Non-production Workers}

\begin{tabular}{|c|c|c|c|c|c|c|c|c|c|}
\hline \multirow[b]{3}{*}{$\begin{array}{l}\text { Sector } \\
\text { Trends }\end{array}$} & \multirow[b]{3}{*}{$\begin{array}{c}\text { Plant } \\
\text { Trends }\end{array}$} & \multicolumn{4}{|c|}{ Expansion Years } & \multicolumn{4}{|c|}{ Recession Years } \\
\hline & & \multicolumn{2}{|c|}{ Production Workers } & \multicolumn{2}{|c|}{ Non-Production Workers } & \multicolumn{2}{|c|}{ Production Workers } & \multicolumn{2}{|c|}{ Non-Production Workers } \\
\hline & & $\begin{array}{c}\text { Wages } \\
(1)\end{array}$ & $\begin{array}{c}\text { Employment } \\
(2)\end{array}$ & $\begin{array}{c}\text { Wages } \\
(3)\end{array}$ & $\begin{array}{c}\text { Employment } \\
(4)\end{array}$ & $\begin{array}{c}\text { Wages } \\
(5)\end{array}$ & $\begin{array}{c}\text { Employment } \\
(6)\end{array}$ & $\begin{array}{c}\text { Wages } \\
(7) \\
\end{array}$ & $\begin{array}{c}\text { Employment } \\
(8)\end{array}$ \\
\hline NO & $\mathrm{NO}$ & $\begin{array}{l}-0.0802 \\
(0.0485)\end{array}$ & $\begin{array}{c}-0.2782 \\
(0.0228)\end{array}$ & $\begin{array}{l}-0.2252 \\
(0.0532)\end{array}$ & $\begin{array}{c}-0.2119 \\
(0.0706)\end{array}$ & $\begin{array}{l}-0.0798 \\
(0.0394)\end{array}$ & $\begin{array}{l}-0.2094 \\
(0.0872)\end{array}$ & $\begin{array}{c}-0.1006 \\
(0.0644)\end{array}$ & $\begin{array}{c}-0.1944 \\
(0.0734)\end{array}$ \\
\hline YES & $\mathrm{NO}$ & $\begin{array}{c}-0.0683 \\
(0.0462)\end{array}$ & $\begin{array}{l}-0.4013 \\
(0.0608)\end{array}$ & $\begin{array}{l}-0.2683 \\
(0.0339)\end{array}$ & $\begin{array}{c}-0.2008 \\
(0.0742)\end{array}$ & $\begin{array}{l}-0.1094 \\
(0.0526)\end{array}$ & $\begin{array}{l}-0.3246 \\
(0.0764)\end{array}$ & $\begin{array}{l}-0.1897 \\
(0.0964)\end{array}$ & $\begin{array}{c}-0.1974 \\
(0.0471)\end{array}$ \\
\hline $\mathrm{NO}$ & YES & $\begin{array}{c}-0.1394 \\
(0.0647)\end{array}$ & $\begin{array}{l}-0.5492 \\
(0.0811)\end{array}$ & $\begin{array}{l}-0.2893 \\
(0.0697)\end{array}$ & $\begin{array}{l}-0.4897 \\
(0.0632)\end{array}$ & $\begin{array}{l}-0.1459 \\
(0.1046)\end{array}$ & $\begin{array}{c}0.5143 \\
(0.1247)\end{array}$ & $\begin{array}{l}-0.2753 \\
(0.0942)\end{array}$ & $\begin{array}{l}-0.4381 \\
(0.1127)\end{array}$ \\
\hline
\end{tabular}

Notes: The table reports results from regressions of first-differences specifications without sector and firm effects, with sector effects and with firm effects using data for 1983-84 and 1989-90 for the expansion years and using data for 1984-85 and 1988-89 for the recession years. Standard errors are in parenthesis. 
Figure 1: Distribution of Tax Rate Changes between 1984 and 1985

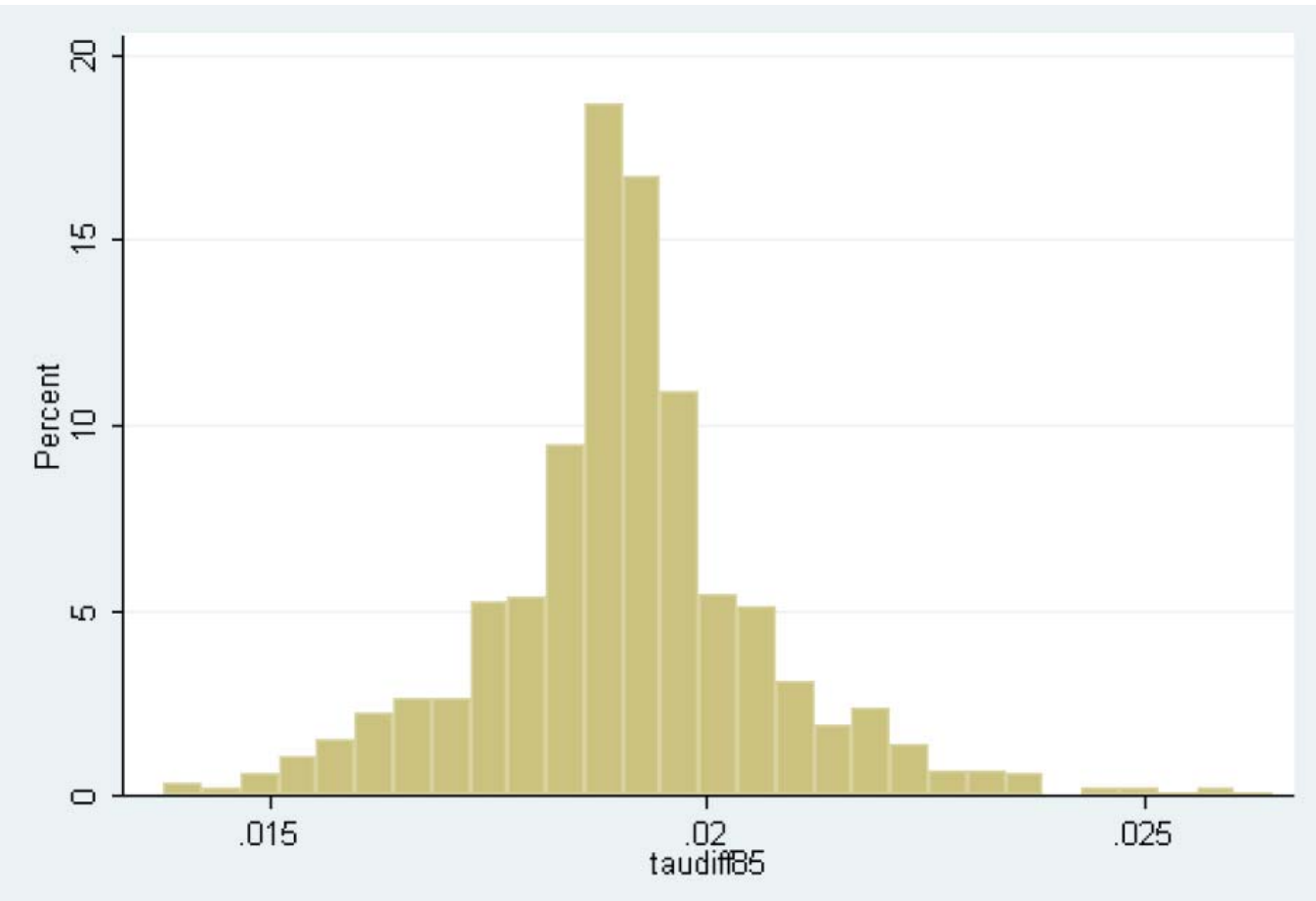

Figure 2: Distribution of Tax Rate Changes between 1988 and 1989

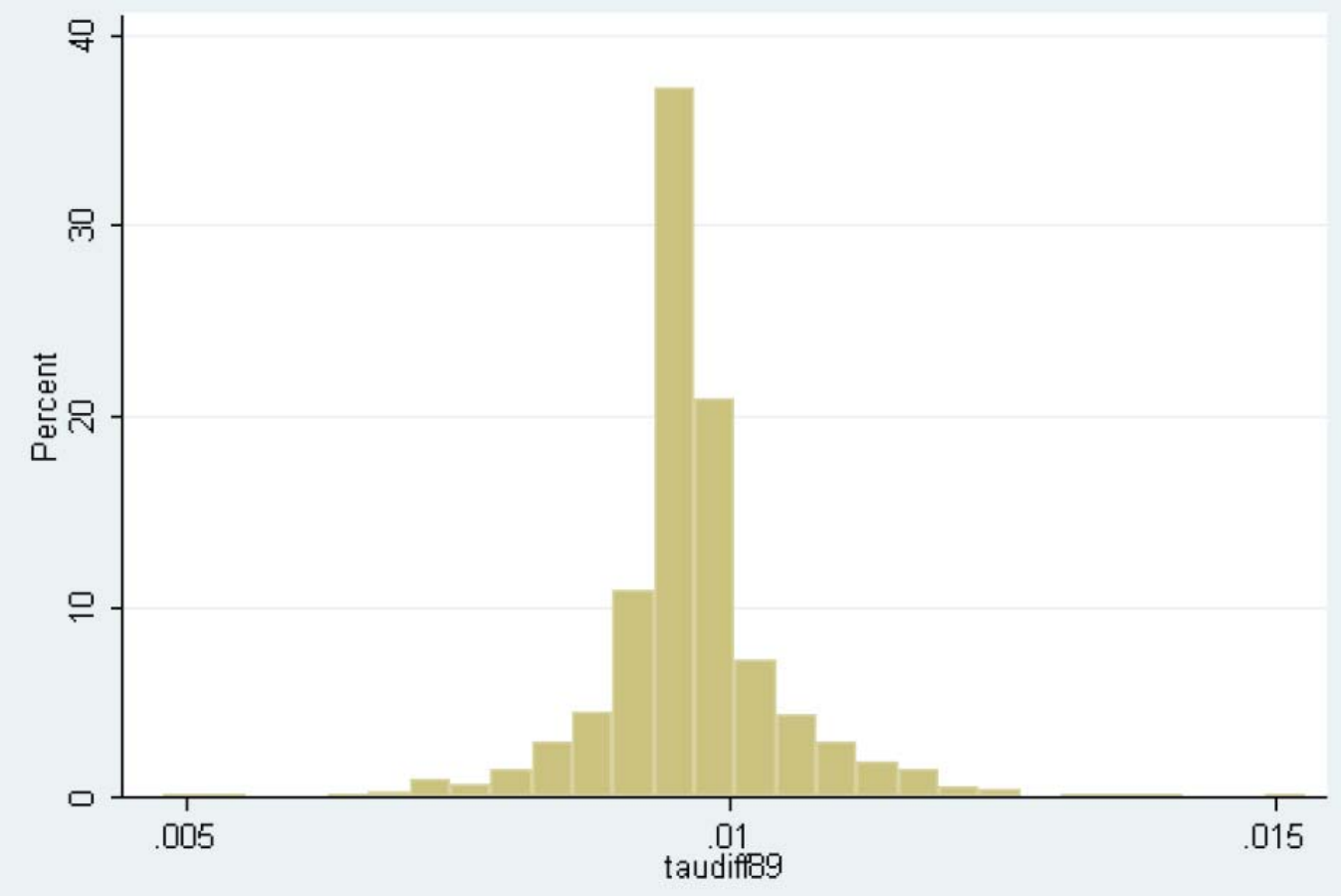


Figure 3: Distribution of Tax Rate Changes between 1983 and 1984

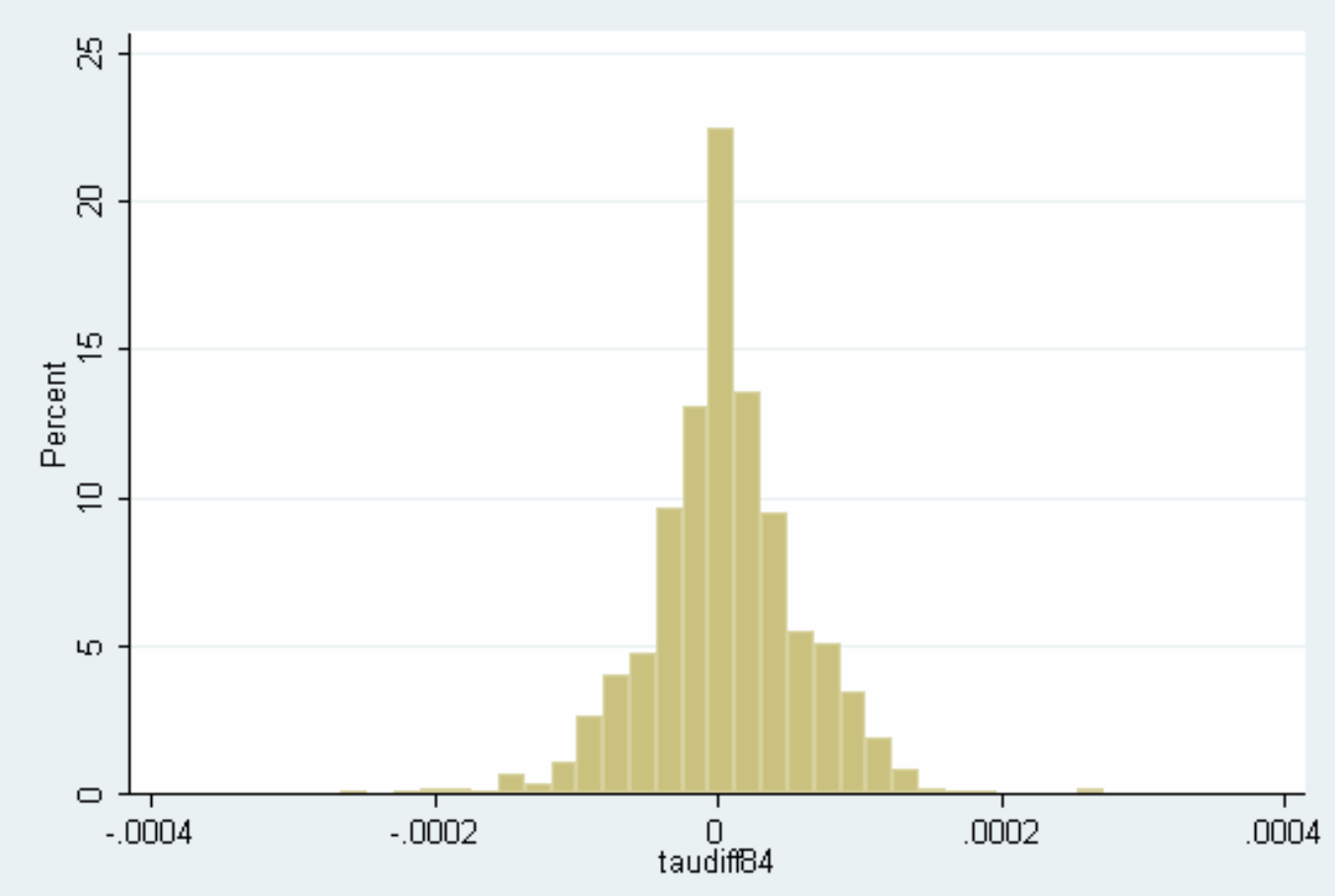

Figure 4: Distribution of Tax Rate Changes between 1989 and 1990

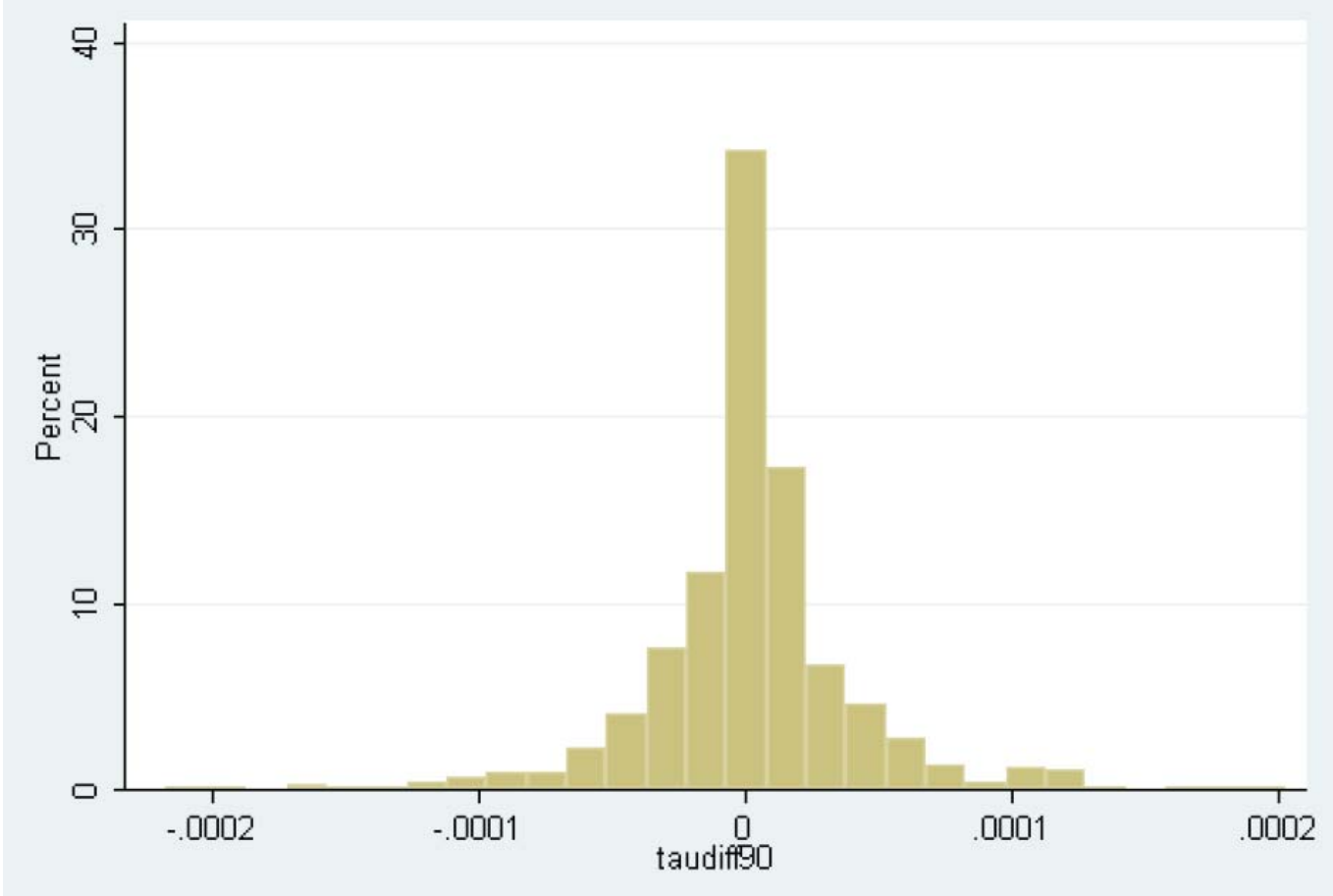


Figure 5: Distribution of Tax Rate Changes between 1993 and 1994

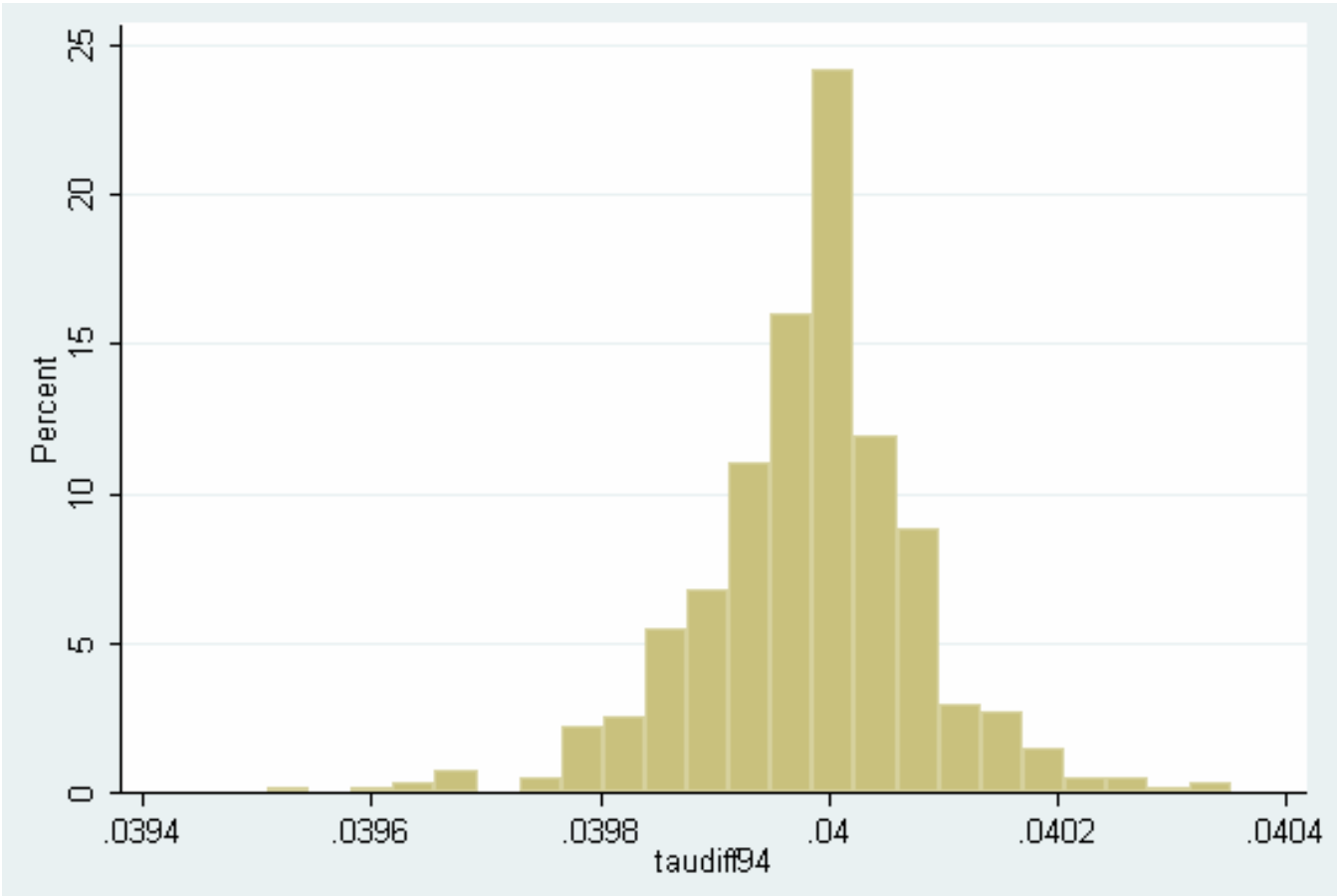

Figure 6: Distribution of Tax Rate Changes between 1995 and 1996

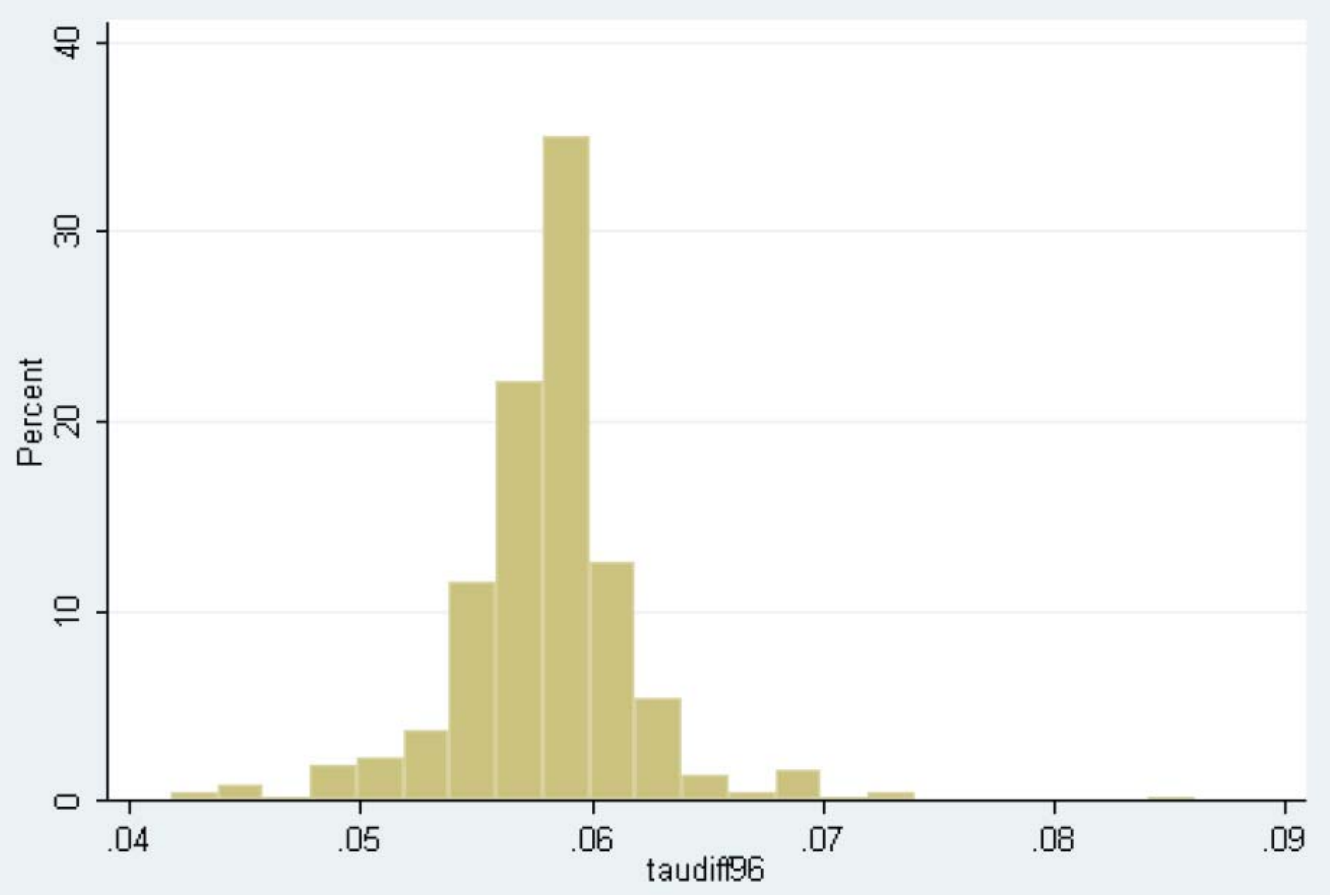

